\section{SAGE Journals}

\section{About}

Privacy Policy

Terms of Use

Contact Us

Help

Accessibility

\section{Browse}

Health Sciences

Life Sciences

Materials Science \&

Engineering

Social Sciences \& Humanities

Journals A-Z

Discipline Hubs

\section{Resources}

Authors

Editors

Reviewers

Librarians

Researchers

Societies
Opportunities

Advertising

Reprints

Content Sponsorships

Permissions

Microsites
Public Finance

Review

ISSN: 1091-1421

Online ISSN: 1552-7530

Copyright $\odot 2020$ by SAGE Publications 


\title{
Public Finance Review
}

\author{
Table of Contents
}

\author{
Volume 34 Issue 3, May 2006
}

\section{Articles}

(1) Cognition, Incentives, and Public Governance: Laboratory Federalism from the Organizational Viewpoint

Giampaolo Garzarelli

First Published May 1, 2006; pp. 235-257

Abstract

$>$ Preview

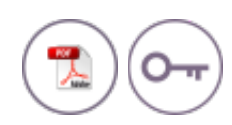

(I) Competition over the Tax Base in the State Sales Tax

Jason M. Fletcher, Matthew N. Murray

First Published May 1, 2006; pp. 258-281

Abstract

$>$ Preview

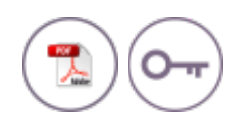

(1) Income Inequality and Redistributive Government Spending

Luiz de Mello, Erwin R. Tiongson

First Published May 1, 2006; pp. 282-305

Abstract

> Preview 


\section{(2) 0}

(1i) On Dynamic Tax Reform with Regime Switching

Wen-ya Chang, Hsueh-fang Tsai

First Published May 1, 2006; pp. 306-327

Abstract

$>$ Preview

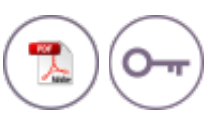

Correction:

Erratum

(1) Estimating Public Library Efficiency Using Stochastic Frontiers

Jeffrey Andrew Hemmeter

First Published May 1, 2006; pp. 328-348

Abstract

$>$ Preview

(2) 


\title{
Laboratory Federalism from
} the Organizational Viewpoint

\author{
Giampaolo Garzarelli \\ Università degli Studi di Roma, \\ "La Sapienza," Rome, Italy
}

\begin{abstract}
The second-generation theory (SGT) of fiscal federalism, which draws upon contemporary economic and industrial organization theory, hitherto focuses only on the negative benefits of public decentralization: the potentially superior ability to align perverse incentives vis-à-vis the centralized governance alternative. The SGT neglects the positive benefits of decentralization (mistakeridden learning, flexibility, and option discovery), although the limitations of organization theory do not justify such neglect. By likening intergovernmental grants to incomplete contracts, this work shows that the SGT can include the laboratory nature of decentralization.
\end{abstract}

Keywords: experimentation; incomplete contracts; intergovernmental grants; learning; second-generation theory of fiscal federalism

[The] basic problem facing public and private policy [consists in] the design of institutional arrangements that provide incentives to encourage experimentation (including the development of new products, knowledge, and new ways of organizing activities) without overly insulating these experiments from the ultimate test of survival.

—Harold Demsetz $(1969,20)$

\begin{abstract}
A ccording to public economic theory, one of the benefits that derives from fiscal federalism-or the economic decentralization of public governance-is that it can act as a laboratory of rapid trial-and-error learning for public policy. ${ }^{1}$ Viscount Bryce's contention is a classic synthesis of this belief. "Federalism enables a people to try experiments in legislation and administration which could not be safely tried in a large centralized country. A comparatively small commonwealth like an American state easily makes and unmakes its laws; mistakes are not serious, for they are soon corrected; other states profit by the experience of a law or a method
\end{abstract}


which has worked well or ill in the state that has tried it" (Bryce [1888] 2004, 257). ${ }^{2}$

Until now, the primary theoretical framework employed to study the belief that ascribes a beneficial cognitive role to decentralization originates from public economics (Rose-Ackerman 1980; Strumpf 2002). This article takes a different tack. Its main objective is to discuss the laboratory role of fiscal federalism not from the more familiar public economics viewpoint but from an organizational viewpoint.

Recently, Oates $(1999,1120)$ suggested that we can think of the theory of fiscal federalism organizationally: as a theory about the division of labor between the local governments and the central one. Others have conducted studies where fiscal federalism is viewed as mainly a problem of organizational design. Drawing on principal-agent, new institutional (or transaction cost) economics, and new property rights theories, this line of work is basically interested in determining the organizational alternatives best suited to minimize the deadweight losses generated by the pervasive misaligned incentives present in public organization. ${ }^{3}$ These insightful studies represent an important first step in demonstrating that public economics is not the only useful theoretical framework to study public decentralization.

Qian and Weingast (1997) dub this emerging literature that tries to look at fiscal federalism in more explicit organizational terms as the secondgeneration theory (SGT) of fiscal federalism. This article is a contribution to the SGT. Studying fiscal federalism does not merely mean analyzing the negative benefits of federalism (i.e., incentive alignment), but also the positive ones (i.e., mistake-ridden learning). What should accordingly occupy our attention is not only a comparative institutional analysis hinging on the minimization of rent seeking costs but also a comparative institutional analysis hinging on the generation of productive contexts. Various forms of economic organization may surely arise for limiting unproductive behaviors

Author's Note: The author thanks Francis Antonie, Rashad Cassim, Davide Consoli, Antonio Maria Fusco, Pierre Garrouste, Elizabeth Geoghegan, Dan Johansson, Elias L. Khalil, Roger Koppl, Richard N. Langlois, Yasmina Reem Limam, Neil Rankin, Christian Schubert, Richard E. Wagner, Harry Zarenda and, above all, the two referees for very insightful and helpful feedback. He must, however, single out Wallace E. Oates for his unstinting help on various preliminary drafts. Previous versions of this article were presented at the November 21 to 23, 2004, SEA/SDAE meeting in New Orleans; at the School of Economics and Business Sciences, University of Witwatersrand, on September 12, 2005; and at the 46th scientific meeting of the Società Italiana degli Economisti, October 21 to 22, 2005, in Naples. At the time of the first draft of this work, the author was also an adjunct at the American University of Rome, the generous financial support of which he gratefully acknowledges. The author holds the property rights to all remaining errors, misinterpretations, and misunderstandings. 
originating from various sources (e.g., from indivisibilities in team production, from soft budget constraints). However, they may also arise to channel and generate productive behaviors in various ways (Pelikan 1988; Langlois 2002; Langlois and Foss 1999; Langlois and Robertson 1995).

Yet, no work has addressed the positive role of fiscal federalism from an organizational viewpoint. One way to balance the situation within the SGT is to consider problems of incentives (or commitments) in conjunction with problems of cognition. Since self-interest cannot be eliminated completely, efficacious economic organization must simultaneously address both problems: the use and discovery of the appropriate knowledge about how to achieve desired objectives and the properly aligned incentives to act on the appropriate knowledge. As Madison writes in Paper No. 62 of The Federalist, a "good government implies two things: first, fidelity to the object of government, which is the happiness of the people; secondly, a knowledge of the means by which that object can be best attained" (Hamilton, Jay, and Madison [1787-1788] 2001, 322).

In this spirit, this article addresses, through the prism of the economics of organization, the positive role that public decentralization can play. Briefly stated, my position is that the SGT needs also to consider the cognitive advantages (adaptation, trial-and-error learning, experimentation) that fiscal federalism - if compared to its unitary alternative-can yield in concomitance with its incentive alignment advantages. This includes ascertaining preferred fiscal (and other public, including incentive mechanism design) institutional and organizational choices that, under currently understood alternatives, may not even be known.

\section{Old and New Theories of Fiscal Federalism}

According to received theory, a fundamental role of the central government in a federation is to offset, by means of a subsidy, the external effects that may emerge among local governments. For instance, paving a road in one jurisdiction may create beneficial effects in another jurisdiction and thus generate the problem of interjurisdictional internalization. In cases such as this, the central government intervenes by subsidizing the local government with Pigouvian unit subsidies (or matching grants) to internalize the external benefits. The beneficiary government will solve the spillover problem by ensuring that the spatial production scope of the local public good will overlap with the spatial consumption scope of that same local public good or, seen from a different viewpoint, until the federation's marginal social benefits equal marginal cost. 
Plainly, this is a policy answer that rests on a traditional market failure argument the presumption of which is that both central and local governments act in the public interest. The central discontent that currently motivates the SGT literature regards the presumption innate in cases such as the one illustrated by this example. Much like the neoclassical theory of the firm before Coase (1937), previous approaches to fiscal federalism-or so-called first-generation theory (FGT) of federalism-consider the state as nothing more than a black box. This black box interpretation, where the assumed innate benevolence of government solves all problems, is traceable to the Arrow, Musgrave, and Samuelson public finance tradition. ${ }^{4}$

Inspired especially by de Tocqueville ([1835] 1990), Oates's Fiscal Federalism (1972) is the classic theoretical statement of such tradition within the FGT. Implicitly taking the question of the internal structure of the state as a residual, Oates's normative proposition, known as the "decentralization theorem," establishes that "in the absence of cost-savings from the centralized provision of a good and of interjurisdictional external effects, the level of welfare will always be at least as high (and typically higher) if Pareto-efficient levels of consumption of the good are provided in each jurisdiction than if any single, uniform level of consumption is maintained across all jurisdictions. In this way the theorem establishes, in the absence of other kinds of offsetting benefits from centralized control, a presumption in favor of decentralized finance" (Oates 1972, 54, original emphasis). The justification, by Oates's $(1999,1122-4)$ own admission, is disarmingly simple. There's a higher probability of matching local public good demand if public good supply is not centralized (i.e., uniform across jurisdictions). When the theorem does not hold, the central government, acting in the public interest, will internalize interjurisdictional externalities via grants-in-aid.

The SGT claims that the public interest view innate into the FGT exists because of the exogeneity of state organization. But if we look inside the black box of state organization, continues the SGT, then it follows that the three putative roles of allocation, distribution, and stabilization confined to the state by the FGT are performed by a complex public organization that is characterized by more problems than the familiar theory of public economics would lead us to conclude. As a result, investigative efforts should be more focused on studying the state qua organization: state structure, similarly to firm structure, is an organizational design problem. And the point is that often the practical workings of the implemented organizational design are not smooth: various problems (e.g., corruption, shirking, opportunism) plague state and firm organization alike. 
In particular, the SGT highlights how organization theory can offer useful insights into various problems of perverse incentives (or weak commitments) innate in the structure of the public sector. The basic assumption, in fact, is that public organizations are not populated by individuals (bureaucrats, ministers, political representatives) who always necessarily pursue the common good but by individuals who also have utility-maximizing agendas of their own. As a result, the challenge is to design organizations (e.g., federal states) and institutions (e.g., constitutions) that cure such problems by aligning various types of perverse incentives (or creating more credible commitments). Decentralization of public governance could be seen as the "best way to create incentives for politicians to differentiate adequately between the needs of different groups of their citizens" (Seabright 1996, 64).

This is not to say that in economics and political science there were not earlier approaches putting forth similar ideas. The earliest contribution proposing the explicit use of organization theory is arguably Boschken (1982). Moreover, the Public Choice school made public organization writ large a substantial part of its research program (Vanberg and Buchanan 1986; Breton [1985] 1987, 1996; Breton and Scott 1978). ${ }^{5}$ Likewise, the work of Ostrom and coauthors in political science was equally forerunning (Ostrom 1987; Ostrom and Ostrom 1965; Ostrom, Tiebout, and Warren 1961). ${ }^{6}$ A more recent related model is the law and economics one by Cooter (2000).

Germane approaches notwithstanding, the SGT remains a major step forward because of the many novel insights it derives from a well-developed body of theory that exists in economic and industrial organization. Yet, at its current stage, the SGT leaves out the laboratory role of fiscal federalism, even though there is no concrete theoretical reason or objective limitation that renders this ineluctable.

A contemporary industrial and economic organization literature exists, even if perhaps less known, that is able to complement the SGT so as to accommodate the positive (cognitive) as well as the negative (incentive) role of public decentralization. This literature is inspired by contributions that, to a large extent, overlap with those of the better known incentive alignment approach. ${ }^{7}$ In a nutshell, it sees differential knowledge, innovation (organizational, technological, of policy), specialization, and mistakeridden learning as central explanatory variables. ${ }^{8}$

More generally, this literature points out that different governance structures not only differ in their ability to internalize externalities but also differ in their ability to create externalities in the form of productive contexts 
not otherwise achievable. In this literature, moreover, the role of incomplete contracts - the institutional complement of economic organization-is not just about who should have the property rights of decision making on the basis of a least welfare loss criterion. The complementary role of incomplete contracts also manifests itself in the comparative ability of alternative governance structures to facilitate adaptation to positive contingencies. Once the purpose of alternative structures is cast in these other terms, we see that a framework that has been produced for the study of organization can be adapted for our purposes.

Somewhat paradoxically, we shall see in what follows that-at the level of the motivation for decentralization - the cognitive approach innate in my discussion accords more with the FGT (Oates 1972, 1999) than with the SGT as developed so far. Yet, at the substantive level — that is, at the level about how agents acquire and possess knowledge-we shall see that the FGT makes knowledge assumptions that are stronger than those that it makes at the level of motivation. For example, the FGT assumes central government ignorance about local preferences but not about national ones, and this obviously raises some problems about the general ability of a central government to internalize interjurisdictional spillovers by means of Pigouvian subsidies. Still, this does not simultaneously mean that the SGT has, until now, necessarily provided a satisfactory answer to such a cognitive problem. For instance, the SGT does not at all envision an organizational role for intergovernmental grants (Oates forthcoming).

A part of my argument conversely proposes that it is possible to consider grants as the fiscal federalism counterpart of incomplete contracts. Such parallel, i.e., grants as incomplete contracts, suggests that the degree of vagueness inherent in different types of grants can actually serve as a control variable for policy to create incentives to search for and learn about previously unknown alternatives. In brief, during our exploration of the broader organizational role of fiscal federalism, we will also be led to an institutional exploration of intergovernmental grants, which the FGT treats in noninstitutional terms and the current SGT, to the best of my knowledge, simply has not considered yet.

\section{Colocation in Economic Organization}

Analogously to the FGT, the primary motivation behind the organizational approach to fiscal federalism followed here regards the inability to obtain a one-to-one correspondence between the spatial consumption of a 
public good and the full payment for such consumption. One reformulation of such deficiency in "fiscal equivalence" - to use Olson's (1969) expressionis to ask what information or knowledge barriers impede a market clearing as well as what mechanism design options are at our disposal to overcome such barriers.

A fundamental barrier to fiscal equivalence may itself be organizational. When Oates remarks with reference to Tiebout's (1956) approach that the optimal amount of public good provision varies with jurisdiction, notwithstanding mobility, he is making exactly this claim. ${ }^{9}$

[The] gains from decentralization, although typically enhanced by ... mobility, are by no means wholly dependent on them. ... In fact, if there were absolutely nothing mobile-households, factors, or whatever - there would still exist, in general, gains from decentralization. The point here is simply that even in the absence of mobility, the efficient level of output of a "local" public good, as determined by the Samuelson condition that the sum of the marginal rates of substitution equals marginal cost, will typically vary from one jurisdiction to another. To take one example, the efficient level of air quality in Los Angeles is surely much different from that in, say, Chicago. (Oates 1999, 1124; emphasis added)

This observation that sneaks comparative institutional reasoning in the back door is not inconsequential. This is so for two related reasons. First, it focuses attention on different organizational arrangements for the obviation not only of physical and spatial externalities, such as nuisance and pollution, but also of those concerning production and exchange—or, in a word, knowledge. Second, the emphasis on knowledge externalities does not a priori rule out that some organizational arrangements emerge not only to obviate detrimental but also to generate beneficial externalities of the same (and other) type. ${ }^{10}$ This other reading of the problem of fiscal federalism enables us to more explicitly consider its laboratory or cognitive role from the organizational viewpoint.

Jensen and Meckling $(1992,251)$ assert that efficacious economic organization must solve two different kinds of problems: "the rights assignment problem (determining who should exercise a decision right), and the control or agency problem (how to ensure that self-interested decision agents exercise their rights in a way that contributes to the organizational objective)." Efficacious economic organization then requires that the appropriate knowledge and decision rights dovetail or, as they say, colocate. The ways that such colocation of rights to act and knowledge can take place are fundamentally two: one "is by moving the knowledge to those with the decision 
rights; the other is by moving the decision rights to those with the knowledge" (Jensen and Meckling 1992, 253).

We may think of these two available options to address the colocation problem as being the institutional constraints of the problem of economic organization. In different terms, the possible colocations of rights and knowledge define the possible variants of (private as well as public) organizational choices. Given such constraint, one "efficiency" criterion to evaluate organizational forms on a comparative basis may reside in their relative ability to facilitate colocation of knowledge and decision making, a criterion seldom considered in the literature.

These considerations are important for the remainder of the discussion. But before proceeding, allow me to be a little more precise by drawing on both Jensen and Meckling (1992) and Langlois (2002).

The colocation of decision rights to knowledge is possible only in markets. The market permits one to sell or exchange the decision rights that accompany his or her knowledge to act. This is not possible in internal organization. For example, a bureaucrat or politician cannot (legally) sell (or exchange) his or her job to someone else and capture proceeds from such alienation. So in a market the division of labor among the actors is defined not by central design but spontaneously through the various interactions of the actors involved.

At the same time, the colocation of knowledge to decision rights can instead take place in various ways in internal organization; that is, there are several internal organization governance structures that colocate knowledge to decision rights, implying that in this case the difference among governance structures resides in the degree of decision right autonomy rather than in the direction of the colocation per se. For instance, we may have that the ultimate decision rights are strongly centralized, such as in the case of fordist production (a rigid vertical organization of the division of labor) or of a unitary form of government. This can take place because the knowledge that needs to be transmitted among the actors is not (or believed to be not) large in quantity and because the tasks that need to be performed are well defined and not complicated. Even in cases where tasks are more complicated but still well defined, centralized division of labor is still feasible. The point here is that the ultimate decision rights stay on top of the hierarchy, notwithstanding the fact that a few basic rights are distributed along the way.

But within the colocation of knowledge to the decision rights institutional constraint - namely, the internal organization option — there are also more decentralized alternatives available. One straightforward illustration is a strategic network alliance composed of different firms that desire to share some know-how. In this case, ultimate decision rights are present both 
Figure 1

Colocation Options and Governance Structures

\begin{tabular}{|c|c|c|}
\hline & Rights to Knowledge to Act & Knowledge to Rights to Act \\
\hline $\begin{array}{c}\text { Governance } \\
\text { Structures }\end{array}$ & Market & $\begin{array}{c}\text { Various types of internal organization } \\
\text { (e.g., Microsoft, Department of } \\
\text { Defense, unitary state, fiscal federalism, } \\
\text { strategic alliance, university, etc.) }\end{array}$ \\
\hline
\end{tabular}

across and within the allied firms. For example, allied automobile firms may, for a period of time, share the ultimate decision rights about which common chassis design to adopt for a line of their automobile models. Simultaneously, however, the manufactures have the ultimate decision rights to pursue different individual strategic plans, as actually occurred in the case of FIAT, Renault, Saab, and Volvo in Europe some years ago. Another obvious example that comes to mind is a university. In a university, we have different departments, each having ultimate decision rights about how to organize their own majors. Nonetheless, the majors must be compatible with the courses and majors offered in other departments, with the universitywide general education program, with the overall mission of the university, and with external accreditation agencies.

The more pertinent example, of course, is fiscal federalism. So long as the objectives of local jurisdictions do not, for example, conflict with those established by the federal constitution, in this governance structure, some knowledge to ultimate decision rights to act is delegated to the local jurisdictions in the attempt to reach and maintain fiscal equivalence. When fiscal equivalence is not maintained through time because, say, some novel unexpected problem crops up, it may be necessary to experiment with multiple knowledge to rights colocation solutions in order to return to fiscal equivalence. Differently put, it may be necessary to try out multiple degrees of decentralization.

Thus, the rights to knowledge to act and the knowledge to rights to act are the fundamental rules of the organizational game. But while the former option applies only to markets, there are a variety of internal organization governance structures to which the latter can apply. In consequence, the rights/knowledge distinction lets us define the governance structures according to the extent of decentralization/centralization rather than according to decentralization 
Figure 2

An Organizational Spectrum

\begin{tabular}{ll}
\hline Unitary state $\longleftrightarrow$ Federal state $\longleftrightarrow$ Independent states \\
$\begin{array}{l}\text { Less decentralized, less } \\
\text { decision right autonomy }\end{array}$ & $\begin{array}{r}\text { More decentralized, more } \\
\text { decision right autonomy }\end{array}$ \\
\hline
\end{tabular}

or centralization as such. Figure 1 offers a summary of colocation options (or institutional constraints) and governance structures.

The main focus of this article is the right-hand box of Figure 1. We can more precisely illustrate such focus along an $x$-axis, as in Figure 2. The various types of internal organization may be distinguished according to the degree of decision right autonomy. For example, we would expect nonfederal countries, such as Denmark, France, Greece, Japan, and Tunisia, to stand somewhere on the left side of the spectrum and federal countries, such as Canada, Germany, South Africa, Switzerland, and the United States, to stand somewhere on the center-right of the spectrum.

In other words, the degree of decision right autonomy in internal organization is not a binary variable or an "all-or-nothing" trade-off (centralize or decentralize?). Rather, though several internal organization alternatives from which to choose from may be known to us or not be beyond our imagination, "good organization" requires that the degree of decision right autonomy per se be, to borrow Hayek's ([1968] 1978) terminology, a discovery procedure (as the bidirectional lines in Figure 2 try to indicate). ${ }^{11}$

For an individual organization, this means that the degree of decision right autonomy may depend on the nature of the problem that needs to be solved. The more ill defined the problem that we face, the more likely it is that we may need to discover new knowledge to solve it, ${ }^{12}$ for in uncertain environments what matters the most is not optimization but adaptation (Nelson and Winter 1977; Dosi 1988; Pelikan 1988; Langlois 2002). Adaptation (whether one considers private or public organizational contexts ${ }^{13}$ ) may require investing in the knowledge of others through increased decentralization. ${ }^{14}$

Such suggested approach to comparing organizational alternatives resonates with the FGT. The "most useful way for an economist to approach" fiscal federalism "is to treat federalism not in absolute but in relative terms." 
We "can envision a spectrum of structures of the public sector along which the difference is essentially one of degree rather than kind. At one end of the spectrum is a unitary form of government with all decisions made by the central authority, and at the opposite pole is a state of anarchy. Aside from the two polar points themselves, the other positions on the spectrum represent federal organizations of the public sector moving from a greater to a lesser degree of centralization of decision-making" (Oates 1972, 18).

Perhaps more interesting, the approach resonates with the SGT as well. The more we move toward more decentralization along Figure 2, the more we approximate a Coase theorem-like result-arguably, the governance structure closest to the pure market one of the left-hand box of Figure 1. The closer we are to such result, the more likely that the familiar incentive problem will be solved. Why? Because the more a right becomes alienable, the more likely we are to operate under a governance structure that is able to communicate the value of the right in every point in time. If this is the case, then the incentives for the possessor of the right to act to use it capably are crowded in automatically. (We will return to the point below.) There is a complementary aspect. If incentives are crowded in automatically, then some cognitive attention is spontaneously redirected from limiting perverse incentives toward other tasks, such as those involving option discovery through learning from experimentation. ${ }^{15}$

So, what is often at stake are both the alignment of incentives in the face of well-defined situations and the ability to continuously take advantage of differential knowledge when the challenge faced is ill defined. In such ill-defined cases, as discussed presently, the devolution of tasks widens the learning function to include not just one's failures and successes but that of others too. Take note that such widening of options does not exclude the discovery of new incentives that, per se, may stimulate the search for novelty. Framing matters in these terms gives a more explicit flexibility or versatility twist to the organizational approach of the SGT.

\section{Longer, Incomplete Contracts as Incentives to Experiment}

Our thesis - that, because uncertain problems incorporate difficult ones, the positive heuristic of the SGT should simultaneously include the cognitive as well as the incentive alignment role played by fiscal federalism-has brought to the fore the possibility of sketching a division of labor between the central government and the local ones from a different angle. 
This different angle suggests that the problem of economic organization in a federal system should be approached according to a knowledge-to-rightsto-act colocation criterion. Such a criterion in turn implies that one way for federalism to act as a laboratory is to experiment with different combinatorics between knowledge and rights to act in internal organization. Now the question is, how do we create incentives for such experimentation? Or, posing the same question somewhat more precisely, what institutional instruments are at our disposal to stimulate the search for novelty in a federally organized political governance structure?

This is a multifaceted question that we will attempt to answer through successive approximations both here and in the next section. To begin, we need to refer more explicitly to the crucial role that the institution of incomplete contracts generally plays for economic organization.

Just like in its organizational counterpart, in the SGT contractual incompleteness is dominantly seen negatively, for it leaves scope for parasitic behavior, such as opportunism, rent seeking, and shirking. When one desires to achieve a specific objective, it is suggested that an organizational contract is a self-imposed constraint grounded on the belief that there can be gains from trade if one credibly commits to certain behaviors. It is a means to promote specialization because allowing for too much flexibility in action can be equivalent to limiting the ability of others to plan their own purposive action. By limiting the feasible set, parties can make themselves better off. This is a counterintuitive result that rests on the belief that too much flexibility in action is equivalent to limiting the ability of others to plan their own purposive action. This is why the longer contracts of vertical integration are said to effectively supplant the spot contracts of market relations. ${ }^{16}$

Fortunately, analogously to our overarching organizational discussion, we need not elaborate a theory of incomplete contracts from scratch to show that they also have a positive property. The seminal article of economic organization theory, namely, "The Nature of the Firm," is clear.

[Owing] to the difficulty of forecasting, the longer the period of the contract is for the supply of the commodity or service, the less possible, and indeed, the less desirable it is for the person purchasing to specify what the other contracting party is expected to do. It may well be a matter of indifference to the person supplying the service or commodity which of several courses of action is taken, but not to the purchaser of that service or commodity. But the purchaser will not know which of these several courses he will want the supplier to take. Therefore, the service which is being provided is expressed in general terms, the exact details being left for a later date. All that is stated in the contract is the limits to what the person supplying the commodity or service is 
expected to do. The details of what the supplier is expected to do are not stated in the contract but are decided later by the purchaser. When the direction of resources (within the limits of the contract) becomes dependent on the buyer in this way, that relationship which I term the "firm" may be obtained. . . A firm is likely, therefore, to emerge in those cases where a very short-term contract would be unsatisfactory. It is obviously of more importance in the case of services-labor-than it is in the case of the buying of commodities. In the case of commodities, the main items can be stated in advance and the details which will be decided later will be of minor significance. (Coase 1937, 391-2)

In this passage, Coase highlights how the longer incomplete contracts that characterize the firm are instruments of flexibility, of adjustment to unforeseen contingencies, and of continuous bargaining. ${ }^{17}$ Moreover, the more abstract or uncertain the nature of the transactional relationship that ties contractual parties, the more likely that spot contracts will be supplanted by those of the firm. Thus, the fundamental Coasean proposition is that the "distinguishing mark of the firm is the supersession of the price mechanism" (Coase 1937, 389).

Rephrasing Coase's proposition according to our suggested framework, we may say that the market is more likely to be superseded by a knowledge-torights-to-act governance structure the more uncertain or ignorant we are about our alternatives. More generally, on account of their incompleteness, the longterm contracts typical of internal organization governance structures facilitate adaptation through learning thanks to trial-and-error problem solving. ${ }^{18}$

But the relative ability of an organization to learn through experimentation is a function of the nature of its attendant contracts. Even though an organization itself may be considered as a type of heuristic devised to solve a set of related problems having to do with specific organizational ends, the degree of decision right autonomy is a relative, not an absolute, matter. For instance, the more complex is the problem faced, the more probable it is that we need to rely on the knowledge of others through some degree of decentralization to attempt to solve it. Such reliance is a fortiori necessary, moreover, the more uncertain we are about a problem's structure: the more an (efficient?) organization needs to discover previously unknown solution heuristics, the more it will decentralize, other things constant. ${ }^{19}$ This is tantamount to asserting that the greater the extent of contractual incompleteness, the greater the devolution of knowledge to rights to act.

Notice, furthermore, that considering the positive role of organizational contracts implies also recognizing that, within an individual organization, the degree of decision right autonomy is not (or should not be) invariable. To be more specific, an organization's survival requires that its colocations change 
through time as the nature of the problem faced changes, as new problems emerge, and as organizational knowledge grows. ${ }^{20}$ In terms of Figure 2, this means that within a "healthy" organization, we would expect to see the degree of decision right autonomy shifting along the spectrum as situations demanda shifting that is made possible also on account of incomplete contracts.

This section has made the general point that incompleteness of organizational contracts favors the formation of conjectures through the devolution of knowledge to rights to act. In addition, incompleteness favors the productive employment of the solution when it is reached-or, in a word, learning. If organizational contracts were complete, then it would be impossible to accommodate the new knowledge that could emerge through experimentation. An organization, if it could exist at all in a complete contract world, would accordingly come to a halt because it would not be able to discover and adjust to contingencies and hence to endure. The incompleteness of longer, organizational contracts is therefore an incentive to experiment.

\section{Intergovernmental Grants as Incomplete Contracts}

We must now more specifically ask whether there is a fiscal federalism counterpart to incomplete contracts. The answer, I submit, is yes.

The institutional nature of grants - that is, intergovernmental grants as contractual payments among levels of government-was, to the best of my knowledge, first alluded to by Breton and Scott (1978). But it is Brennan and Pincus (1990) who come closest to articulating a contractual theory of grants.

In their attempt to explain the so-called "flypaper effect" (that, contrary to the predictions of theory, the evidence suggests that lump-sum money transfers among levels of governments stick where they hit), Brennan and Pincus suggest considering grants as implicit contracts. In essence, they convincingly argue that a grant can be considered as an open-ended bargaining instrument. They ground this argument on knowledge grounds: the study of the external workings of an institution (e.g., a grant) reveals very little, if anything, about its internal functioning or about how its formal and informal rules and payoff mechanisms work. As a result, they suggest that a grant is often just an instrument of compromise in anticipation of future reciprocal gains. The point to highlight for our purposes is this: a grant may per se be considered a preference revelation mechanism. The selection of type of grant by the donor can send a message to the recipient that to basic price-and-allocation theory would break down, assuming it were possible for 
such theory to articulate it at all in terms of a sufficient statistic: by specifying the type of grant, the donor is (implicitly or otherwise) communicating a preferred spending pattern to the recipient. The flexibility nature of incomplete contracts here enters the stage in its most familiar way: a grant is often just an implicit manifestation of exchange because it embodies a quid pro quo message not otherwise expressible. ${ }^{21}$

Clearly, such interpretation also implies that all grants are at base conditional. To clarify: if a grant is always at base an implicit contract then, no matter its explicit type (e.g., general revenue, specific-purpose nonmatching, and matching), it always conditions the behavior of the recipient. And the conditionality of grants can crowd out experimentation (Breton [1985] 1987, 312-5; Breton 1996, 258). However, the real crux of the matter is that the amount of conditionality (analogously to contractual incompleteness) is not monolithic but can, within the natural bounds dictated by our limited cognition, be varied.

Grants, like contracts, are not all the same. Just as the extent of incompleteness differs for type of contract, so too it differs for type of grant. For example, one expects a constitution to be vaguer than a spot contract and an unconditional block grant to be vaguer than a detailed conditional one. If this is so, it is only rational to attempt to make productive use of the extent of incompleteness. The extent of grant incompleteness can indeed serve as a policy tool. It can be used by a central government in a federation to induce different levels of experimentation from its local governments.

In a setting of transparent preference revelation with a well-defined objective function, it is possible to perform comparative-static analyses to see the shifts in the point of tangency of a local community's budget constraint with its iso-welfare curves between a public good and all other goods. Since this is practically an exercise that is fully analogous to the familiar procedure in consumer choice theory, it is straightforward to show that, if interjurisdictional spillover benefits are present, then the income effect engendered by a no-strings-attached block grant produces inferior welfare benefits vis-à-vis a substitution effect engendered by a conditional, matching grant (Oates 1972, chap. 3).

In a setting of less than perfect information, however, it is less trivial to define optimality in every point in time. Moreover, there may exist cases when it is not obvious how to even set up or crisply isolate the problem that one wishes to solve. In these other cases, more experimentation may be called for, and more experimentation may in effect depend on greater autonomy, as opposed to greater restriction, of behavior. Such objective can be achieved by a higher level of grant incompleteness (less conditionality) as opposed to a higher level of grant completeness (more conditionality). 
The benefits of local-level experimentation are especially evident in U.S. environmental policy. ${ }^{22}$ Environmental problems are not homogeneous but vary according to moment and location. They accordingly require "the knowledge of the particular circumstances of time and place" (Hayek 1945, 521) to be solved. Often, such knowledge comes only from specific trial-and-error learning. Thus, many U.S. states have become environmental laboratories, and the results of the local experimentation have spilled over among the states and have shown their fruits in many "green" sectors. For example, at the level of air pollution control, hazardous waste cleaning, and park management the positive results of state-level policy outweigh national ones.

But what is perhaps more interesting in this context is that such statelevel policy experimentation is occurring, notwithstanding the inertia of the federal government to abandon its one-size-fits-all approach. National environmental standards set by the Environmental Protection Agency (EPA) are actually limiting the degree of environmental policy innovation. The EPA standards in fact condition state behavior through sanctions, such as the loss of federal subsidies for highway construction. The limit to a more extensive devolution of environmental policy is justified on grounds of the "race to the bottom" argument. Such argument rests on the assumption that if we let local jurisdictions autonomously search and compete with each other in the hope of discovering the most appropriate policies, then there will actually be a wasteful outcome. It is suggested that this is so because states would attempt to attract and preserve new business investments by decreasing taxes and offering lax environmental standards, and this would lead to suboptimal results (e.g., shortages of local public goods and decreases in environmental quality). The evidence, however, shows that the opposite is taking place. Thus, it highlights and favors the reverse argument: rather than a centralization through federal standards, what seems necessary to maintain and improve the factual "race to the top," as Oates (2002) and others call it, is a policy of greater devolution through grants.

The recent Personal Responsibility and Work Opportunity Reconciliation Act, more simply known as the 1996 U.S. welfare reform, offers another concrete illustration of how a disposition to spread risk over parallel conjectures through increased devolution can be beneficial. ${ }^{23}$ Among other changes, the reform in fact replaces the jointly administered state/federal Aid to Families with Dependent Children matching grant program introduced in the 1930s with a relatively loose new system of block grants, the Temporary Assistance for Needy Families (TANF) Block Grant. The expanded vagueness of grant incompleteness-namely, the move from more to less conditional grants-appears to have created higher powered 
incentives for local governments to try to solve various problems (e.g., unemployment and poor relief).

To point the spotlight on the exchange nature of grants does not simultaneously mean proposing a sort of beggar-thy-central-government policy stance that leads to a race to the bottom in another form. Quite the contrary is the case. As was said earlier, the suggested organizational approach entails that the more we decentralize, the more probable it is that the incentive alignment problem will be solved as well. In a federal system, it is in fact in the interest of the recipient government to competently use donated funds with few strings attached. As with all instances of exchange, failure to do so signifies that the gains from trade engendered thanks to an intergovernmental grant are not reciprocal. If this is so, then there is no reason for a central government to continue in such a transactional relationship. As Wicksell (1958 [1896], 89) concisely asserted long ago, it "would seem to be a blatant injustice if someone should be forced to contribute toward the costs of some activity which does not further his interests or may even be diametrically opposed to them."

Without wanting to push the point too far in the present article, let us note that the absence of a Wicksellian "blatant injustice" in intergovernmental exchange (or the ability to use donated funds "competently" by a recipient government) does not necessarily mean coincidence with the outcomes predicted by the median voter assumption. Intergovernmental grants are characterized by complex political equilibria. Take the flypaper effect. According to our suggested approach, we would expect to see the correspondence between the effect of an increase in income and of a federal grant of the same amount on a public budget (i.e., the absence of a flypaper effect) in two cases: when grants are not considered as institutions or when information is perfect. Ultimately, however, these two cases boil down to one for they rest on a common assumption that there is no knowledge problem. When grants are not considered as institutions, we are throwing away useful information about the nature of politics. When information is perfect, there is no difference: it means that individual and collective preferences match or that the problem faced is well defined. Fundamentally, then, one would expect to see the absence of a flypaper effect only if there is no room for knowledge gains.

From another perspective, one could plausibly argue that the flypaper effect is actually a cost attached to the solution of a bargaining problem, and that to consider such a solution "inefficient" and to opt, for example, for a centralized governance structure in the attempt to go back to the "efficient" path is to propose a policy that does not consider the complete costs of the alternative governance structures (Demsetz 1969; Pelikan 1988). Again, the issue is a comparative institutional one. The knowledge benefits from 
decentralization (with their possible "inefficiencies") may outweigh the static "efficiencies" of centralization.

I therefore hope it is clear that the cognitive or knowledge-based organizational approach to fiscal federalism presented here is not idealistic or secondary to that of incentives. Hamilton's early statement on taxation remains a fine encapsulation of the pragmatic importance of knowledge in matters of public governance.

There is no part of the administration of government that requires extensive information and a thorough knowledge of the principles of political economy, so much as the business of taxation. The man who understands those principles best will be least likely to resort to oppressive expedients, or sacrifice any particular class of citizens to the procurement of revenue. It might be demonstrated that the most productive system of finance will always be the least burdensome. There can be no doubt that in order to a judicious exercise of the power of taxation, it is necessary that the person in whose hands it should be acquainted with the general genius, habits, and modes of thinking of the people at large, and with the resources of the country. And this is all that can be reasonably meant by a knowledge of the interests and feelings of the people. In any other sense the proposition has either no meaning, or an absurd one. And in that sense let every considerate citizen judge for himself where the requisite qualification is most likely to be found. (Hamilton, Jay, and Madison [1787-1788] 2001, Paper No. 35: 172)

\section{Conclusion}

This article has tried to level the theoretical balance within the emerging SGT by highlighting that an organizational approach applied to the study of the vertical structure of the public sector is able to include the laboratory role played by federalism too. As such, it suggests that efficacious economic organization not only constrains unproductive behavior but also enables productive behavior through the devolution of knowledge to rights to act. In developed economies, such devolution - the extent of which can be varied according to type of intergovernmental grant—can create incentives for learning about and discovering previously unknown alternatives. In summary, the article establishes a first approximation argument that shows that we have the industrial and economic organization theoretical machinery to also endogenize the laboratory role of fiscal federalism within the SGT.

Let us conclude by noting that the analysis does not entail that within a federal organizational system some experimentation cannot take place at the level of the central government. For example, the central government in the 
United States has undertaken a number of social experiments, such as the 1960s negative income tax and the housing vouchers. An interesting issue to expand upon from a more explicit organizational stance concerns what kinds of experiments should take place at the different levels of government.

\section{Notes}

1. On the general theoretical notion of institutional and organizational trial-and-error learning, see especially Nelson and Winter (1977).

2. Echoing Viscount Bryce, Justice Louis D. Brandeis asserted in a dissenting 1932 opinion that man "is weak and his judgment is at best fallible. .. . Yet the advances in the exact sciences and the achievements in invention remind us that the seemingly impossible sometimes happens. There are many men now living who were in the habit of using the age-old expression: 'It is as impossible as flying.' The discoveries in physical science, the triumphs in invention, attest the value of the process of trial and error. In large measure, these advances have been due to experimentation. In those fields experimentation has, for two centuries, been not only free but encouraged. Some people assert that our present plight is due, in part, to the limitations set ... by courts upon experimentation in the fields of social and economic science; and to the discouragement to which proposals for betterment there have been subjected otherwise. There must be power in the states and the nation to remould, through experimentation, our economic practices and institutions to meet changing social and economic needs.... To stay experimentation in things social and economic is a grave responsibility. Denial of the right to experiment may be fraught with serious consequences to the nation. It is one of the happy incidents of the federal system that a single courageous state may, if its citizens choose, serve as a laboratory; and try novel social and economic experiments without risk to the rest of the country" (New State Ice Co. v. Liebmann, 1932). See also the opinions of Justice Oliver Wendell Holmes Jr. in Abrams v. United States (1919) and Truax v. Corrigan (1921) who, dissenting, defended the experimental nature of the First and the Fourteenth Amendments, respectively. Justice Brandeis agreed with Justice Holmes in these cases.

3. See Weingast (1995), Crémer, Estache, and Seabright (1996), Seabright (1996), Saiegh and Tommasi (2000), and Tommasi and Weinschelbaum (2003).

4. Oates (forthcoming) places the first-generation theory (FGT) and the second-generation theory (SGT) into a broader context.

5. We will return to the general Public Choice view of political organization toward the end of our story.

6. On Ostrom's contribution to polycentric governance, compare also the June 2005 special issue of the Journal of Economic Behavior and Organization 57 (2).

7. Sources of inspiration are such classics as Coase (1937, 1960), Hayek (1948), Simon (1951, [1962] 1998), Demsetz (1969), and Dahlman (1979).

8. Some representative contributions within this organizational literature are Richardson (1972), Nelson and Winter (1977), Teece (1980), Dosi (1988), Pelikan (1988), Egidi (1992), Langlois (2002), and Langlois and Robertson (1995).

9. For an attempt to link Tiebout (1956) to the SGT, see Garzarelli (2004).

10. Compare Coase (1960), Demsetz (1969), Dahlman (1979), Pelikan (1988), and Langlois (2002).

11. Vihanto (1992) presents a theory of federalism as a discovery procedure. 
12. Compare the following statement by two economists who contributed to the principalagent tradition. A "decisionmaker may not know the alternatives that are available or even those that might possibly be available, and may be forced to rely on interested parties for suggestions. Such uncertainties make it impossible to formulate prior beliefs about the set of alternatives, and so rule out the use of Bayesian decision theory. Uncertainty of this kind is an important aspect of reality" (Milgrom and Roberts 1986, 30).

13. To my knowledge, the first application of evolutionary principles to public as opposed to private economic contexts was done by Forte (1982), which to this day remains a rather neglected contribution.

14. Of course, there are many more variables that may shift the balance: for example, urgency of problem solving or nongradual environmental variation may actually require more centralization (Bolton and Farrell 1990).

15. For an argument that approximates this one in the related context of supranational federalism, see Casella (1999).

16. See, for example, Langlois and Robertson (1995) and Garzarelli and Limam (2003).

17. For a full-blown defense of this point, see Langlois and Foss (1999).

18. On the idea that an organizational hierarchy learns because it is an instance of problem solving, see Simon ([1962] 1998), Loasby (1976), Egidi (1992), and Foss (1996).

19. To compete in the PC market in the early 1980s, for example, IBM did exactly this (see Langlois and Robertson 1995, chap. 5).

20. Madison also alludes to this, especially in Paper No. 38 of The Federalist (Hamilton, Jay, and Madison [1787-1788] 2001, 186-93). As Ostrom (1987, 47) sums it up in his exegesis, "Fallible decision makers must anticipate the possibility of a reconsideration of their situation, a reformulation of their problems, and a change of strategies in light of experience and new information. The condition of human fallibility requires analysis, reason, deliberation, choice, experience, reconsideration, and an opportunity to alter, amend, or change as new information and new understanding give rise to new possibilities. Human life and the constitution of political institutions, as Madison indicates . . . can never be more than a provisional experiment subject to change in light of experience."

21. It is in this guise - the politics as exchange view-that the more general Public Choice organizational view has reentered our story.

22. The environmental discussion that follows mostly draws on Oates (2002).

23. A succinct economic treatment of such reform is Blank (1997).

\section{References}

Abrams v. United States, 250 U.S. 616 (1919).

Blank, Rebecca M. 1997. Policy Watch: The 1996 Welfare Reform. Journal of Economic Perspectives 11 (1): 168-77.

Bolton, Patrick, and Joseph Farrell. 1990. Decentralization, duplication, and delay. Journal of Political Economy 98(4): 803-26.

Boschken, Herman L. 1982. Organization theory and federalism: Interorganizational networks and the political economy of the federalist. Organization Studies 3 (4): 355-73.

Brennan, Geoffrey, and Jonathan Pincus. 1990. An implicit contract theory of intergovernmental grants. Publius: The Journal of Federalism 29 (4): 129-44.

Breton, Albert. [1985] 1987. Towards a theory of competitive federalism. European Journal of Political Economy 3 (1-2): 263-329. 
1996. Competitive governments: An economic theory of politics and public finance. New York: Cambridge University Press.

Breton, Albert, and Anthony Scott. 1978. The economic constitution offederal states. Toronto: University of Toronto Press.

Bryce, James Viscount. [1888] 2004. The American commonwealth, volume 1 (with an "Introduction" by G. L. McDowell). Indianapolis: Online PDF Liberty Fund. http://oll.libertyfund.org/Texts/LFBooks/Bryce0057/AmericanCommonwealth/0004-01_eBk.pdf

Casella, Alessandra. 1999. Tradable deficit permits: Efficient implementation of the stability pact in the European Monetary Union. Economic Policy 14 (29): 323-61.

Coase, Ronald H. 1937. The nature of the firm. Economica, N.S., 4 (16): 386-405

. 1960. The problem of social cost. Journal of Law and Economics 3 (1): 1-44.

Cooter, Robert D. 2000. The strategic constitution. Princeton, NJ: Princeton University Press.

Crémer, Jacques, Antonio Estache, and Paul Seabright. 1996. Decentralizing public services: What can we learn from the theory of the firm? Revue d'économie politique 106 (1): 37-60.

Dahlman, Carl J. 1979. The problem of externality. Journal of Law and Economics 22 (1): 141-62.

de Tocqueville, Alexis. [1835] 1990. Democracy in America, volume I (with a "New Introduction" by D. J. Boorstin). New York: Vintage Classics.

Demsetz, Harold. 1969. Information and efficiency: Another viewpoint. Journal of Law and Economics 12 (1): 1-22.

Dosi, Giovanni. 1988. Sources, procedures and microeconomic effects of innovation. Journal of Economic Literature 26 (3): 1120-71.

Egidi, Massimo. 1992. Organizational learning, problem solving and the division of labor. In Economics, bounded rationality and the cognitive revolution, edited by Massimo Egidi and Robin Marris, 148-73. Aldershot, UK: Edward Elgar.

Forte, Francesco. 1982. The law of selection in the public economy as compared to the market economy. Public Finance/Finances Publiques 37 (2): 224-45.

Foss, Nicolai J. 1996. Firms, incomplete contracts, and organizational learning. Human Systems Management 15:17-26.

Garzarelli, Giampaolo. 2004. Old and new theories of fiscal federalism, organizational design problems, and Tiebout. Journal of Public Finance and Public Choice 22 (1-2): 91-104.

Garzarelli, Giampaolo, and Yasmina Reem Limam. 2003. Knowledge, coordination, and fiscal federalism: An organizational perspective. In I sistemi di welfare tra decentramento regionale e integrazione europea, edited by Daniele Franco and Alberto Zanardi, 231-40. Milan, Italy: FrancoAngeli.

Hamilton, Alexander, John Jay, and James Madison. [1787-1788] 2001. The federalist. Edited with an "Introduction" by G. W. Carey and J. McClellan. Indianapolis, IN: Liberty Fund.

Hayek, Friedrich A. von. 1945. The use of knowledge in society. American Economic Review 35 (4): 519-30.

- 1948. Individualism and economic order. Chicago: Chicago University Press.

- [1968] 1978. New studies in philosophy, politics, economics and the history of ideas. London: Routledge Kegan Paul.

Jensen, Michael C., and William H. Meckling. 1992. Specific and general knowledge, and organizational structure. In Contract economics, edited by Lars Werin and Hans Wijkander, 251-74. Oxford, UK: Basil Blackwell.

Langlois, Richard N. 2002. Modularity in technology and organization. Journal of Economic Behavior and Organization 49 (1): 19-37. 
Langlois, Richard N., and Nicolai J. Foss. 1999. Capabilities and governance: The rebirth of production in the theory of economic organization. Kyklos 52 (2): 201-18.

Langlois, Richard N., and Paul L. Robertson. 1995. Firms, markets, and economic change: A dynamic theory of business institutions. London: Routledge.

Loasby, Brian J. 1976. Choice, complexity and ignorance. Cambridge, UK: Cambridge University Press.

Milgrom, Paul, and John Roberts. 1986. Relying on the information of interested parties. RAND Journal of Economics 17 (1): 18-32.

Nelson, Richard R., and Sidney G. Winter. 1977. In search of useful theory of innovation. Research Policy 6 (1): 36-76.

New State Ice Co. v. Liebmann, 285 U.S. 282 (1932).

Oates, Wallace E. 1972. Fiscal federalism. New York: Harcourt Brace Jovanovich. 1999. An essay on fiscal federalism. Journal of Economic Literature 37 (3): 1120-49.

- 2002. A reconsideration of environmental federalism. In Recent advances in environmental economics, edited by John A. List and Aart de Zeeuw, 1-32. Cheltenham, UK: Edward Elgar.

Forthcoming. Toward a second-generation theory of fiscal federalism. International Tax and Public Finance.

Olson, Mancur, Jr. 1969. The principle of 'fiscal equivalence': The division of responsibilities among different levels of government. American Economic Review, Papers and Proceedings 59 (2): 479-87.

Ostrom, Vincent. 1987. The political theory of a compound republic: Designing the American experiment. 2nd ed., revised and enlarged. Lincoln: University of Nebraska Press.

Ostrom, Vincent, and Elinor Ostrom. 1965. A behavioral approach to the study of intergovernmental relations. Annals of the American Academy of Political and Social Science 359:137-46.

Ostrom, Vincent, Charles M. Tiebout, and Robert Warren. 1961. The organization of government in metropolitan areas: A theoretical inquiry. American Political Science Review 55 (4): 831-42.

Pelikan, Pavel. 1988. Can the imperfect innovation system of capitalism be outperformed? In Technical change and economic theory, edited by Giovanni Dosi, Christopher Freeman, Richard Nelson, Gerald Silverberg, and Luc Soete, 370-98. London: Pinter Publishers.

Qian, Yingyi, and Barry R. Weingast. 1997. Federalism as a commitment to preserving market incentives. Journal of Economic Perspectives 11 (4): 83-92.

Richardson, George B. 1972. The organization of industry. Economic Journal 82 (327): 883-96.

Rose-Ackerman, Susan. 1980. Risk taking and reelection: Does federalism promote innovation? Journal of Legal Studies 9 (3): 593-616.

Saiegh, Sabastian, and Mariano Tommasi. 2000. An 'incomplete-contracts' approach to intergovernmental transfer systems in Latin America. In Decentralization and accountability of the public sector, edited by Shahid Javed Burki and Guillermo E. Perry, 127-44. Washington, DC: World Bank.

Seabright, Paul. 1996. Accountability and decentralization in government: An incomplete contract model. European Economic Review 40 (1): 61-89.

Simon, Herbert A. 1951. A formal theory of the employment relationship. Econometrica 19 (3): 293-305.

- [1962] 1998. The architecture of complexity: Hierarchic systems. In The sciences of the artificial, edited by Herbert A. Simon, 183-216. Cambridge, MA: MIT Press.

Strumpf, Koleman S. 2002. Does government decentralization increase policy innovation? Journal of Public Economic Theory 4 (2): 207-41. 
Teece, David J. 1980. Economies of scope and the scope of the enterprise. Journal of Economic Behavior and Organization 1 (3): 223-47.

Tiebout, Charles M. 1956. A pure theory of local expenditures. Journal of Political Economy 64 (5): 416-24.

Tommasi, Mariano, and Federico Weinschelbaum. 2003. Centralization vs. decentralization: A principal-agent analysis. Unpublished paper.

Truax v. Corrigan, 257 U.S. 312 (1921).

Vanberg, Viktor, and James M. Buchanan. 1986. Organization theory and fiscal economics: Society, state, and public debt. Journal of Law, Economics, and Organization 2 (2): 215-27.

Vihanto, Martti. 1992. Competition between local governments as a discovery procedure. Journal of Institutional and Theoretical Economics 148 (3): 411-36.

Weingast, Barry R. 1995. The economic role of political institutions: Market-preserving federalism and economic growth. Journal of Law, Economics, and Organization 11 (1): 1-31.

Wicksell, Knut. [1896] 1958. A new principle of just taxation. In Classics in the theory of public finance, edited by Richard A. Musgrave and Alan T. Peacock, 72-118. New York: St. Martin's.

From March 2006, Giampaolo Garzarelli is senior lecturer, School of Economic and Business Sciences, University of the Witwatersrand, Johannesburg, South Africa. His main fields of research are the economics of organization, public finance and public choice, and economic and technology policy; his current topics of interest include the second-generation theory of fiscal federalism and the coevolution of technology and organization in open-source software development.

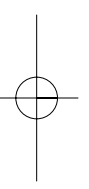

